\title{
Spiritual Emotional Freedom Technique (SEFT) untuk Meningkatkan Kualitas Hidup pada Wanita yang Mengalami Bencana Tanah Longsor
}

\author{
Zuhdan Aftrinanto, Elli Nur Hayati, Siti Urbayatun \\ Universitas Ahmad Dahlan (UAD) Yogyakarta
}

\begin{abstract}
Spiritual Emotional Freedom Technique (SEFT) is engineering the merger of the energy system of the body and spirituality therapy using the method of tapping on certain points on the body. The purpose of this study was to determine the influence of Spiritual Emotional Freedom Technique in improving the quality of life in women who experienced landslide disaster in Purworejo. This study uses a quasiexperimental design with one group pretest-posttest design research model. The subjects of this study were six women in Purworejo with criteria aged 20 to 40 years, experienced landslide disaster, and having a low quality of life based on WHOQOL-BREF scale categorization. The experimental group was treated using the Spiritual Emotional Freedom Technique therapy. Quantitative data analysis techniques using Wilcoxon Signed Rank Test analysis. Qualitative data analysis is obtained from the observation, interview, worksheet, and evaluation sheet. The results showed that there was a significant increase in quality of life, both in each domain and overall between before and after being treated by SEFT. Based on that results, it can be concluded that the SEFT (Spiritual Emotional Freedom Technique) can improve the quality of life of women who experienced a landslide disaster in Purworejo.
\end{abstract}

Keywords: Quality of life; Spiritual Emotional Freedom Technique; woman; landslide

\begin{abstract}
Abstrak
Spiritual Emotional Freedom Technique (SEFT) merupakan teknik penggabungan dari sistem energi tubuh dan terapi spiritualitas dengan menggunakan metode tapping pada beberapa titik tertentu pada tubuh. Tujuan penelitian ini adalah untuk mengetahui pengaruh Spiritual Emotional Freedom Technique dalam meningkatkan kualitas hidup pada wanita yang mengalami bencana tanah longsor di Purworejo. Penelitian ini menggunakan desain kuasi eksperimen dengan model rancangan penelitian one grup pretest - posttest design. Subjek penelitian ini adalah enam orang wanita dewasa di Purworejo dengan kriteria berusia 20 sampai 40 tahun, mengalami bencana tanah longsor, dan memiliki kualitas hidup yang rendah berdasarkan hasil kategorisasi skala WHOQOL-BREF. Kelompok eksperimen diberi perlakuan berupa terapi Spiritual Emotional Freedom Technique. Teknik analisis data kuantitatif menggunakan analisis Uji Wilcoxon Signed Rank Test. Analisis data kualitatif diperoleh dari hasil observasi, wawancara, lembar kerja, dan lembar evaluasi. Hasil penelitian menunjukkan bahwa terdapat peningkatan tingkat kualitas hidup yang signifikan, baik pada masing-masing domain maupun secara keseluruhan antara sebelum dan setelah diberi perlakuan berupa SEFT. Berdasarkan hasil penelitian dapat disimpulkan bahwa SEFT (Spiritual Emotional Freedom Technique) dapat meningkatkan kualitas hidup pada wanita yang mengalami bencana tanah longsor di Purworejo.
\end{abstract}

Kata Kunci: kualitas hidup; SEFT; wanita; tanah longsor 


\section{Pendahuluan}

Negara Indonesia berada di garis khatulistiwa pada posisi silang antara dua benua dan dua samudera. Indonesia pun berada dalam wilayah yang memiliki kondisi geografis, geologis, hidrologis, dan demografis yang rawan terhadap terjadinya bencana dengan frekwensi yang cukup tinggi (Ramli, 2010). Data BNPB (Badan Nasional Penanggulangan Bencana, 2016) menjelaskan bahwa hujan lebat yang turun sejak Sabtu 18 Juni 2016 siang hingga malam hari telah menyebabkan bencana banjir dan longsor yang luas di 16 Kabupaten/Kota di Jawa Tengah yaitu di Purworejo, Banjarnegara, Kendal, Sragen, Purbalingga, Banyumas, Sukoharjo, Kebumen, Wonosobo, Pemalang, Klaten, Magelang, Wonogiri, Cilacap, Karanganyar, dan Kota Solo. Banjir dan longsor dengan korban jiwa terbanyak terjadi di Kabupaten Purworejo. Berdasarkan penjelasan Kepala BPBD Kabupaten Purworejo, Desa Jelok yang terletak Kecamatan Kaligesing merupakan desa yang masih kurang mendapatkan bantuan karena terkendala akses menuju lokasi longsor yang cukup sulit dijangkau dibandingkan daerah terdampak lainnya.

Undang-Undang RI No. 24 Tahun 2007 menyebutkan bahwa bencana alam yang terjadi cukup besar biasanya akan menghilangkan banyak harta benda, nyawa, dan korban luka baik fisik maupun psikologis. Korban bencana tersebut perlu mendapatkan perlakuan yang tepat untuk keamanan mereka. Setiap orang berhak mendapatkan perlindungan sosial dan rasa aman, khususnya bagi kelompok masyarakat rentan bencana. Kelompok rentan terdiri dari wanita, lansia, anak-anak, orang cacat, kaum pendatang, dan penduduk asli setempat (Bizzarri, 2012). Salah satu dampak bencana adalah menurunnya kualitas hidup bagi masyarakat yang menjadi korban (Pan American Health Organization, 2006). Kualitas hidup pada masyarakat yang mengalami bencana alam lebih banyak dipengaruhi oleh tingkat depresi, interaksi sosial, dan jenis kelamin yang menunjukkan bahwa perempuan lebih banyak mengalami kualitas hidup yang rendah dibandingkan dengan laki-laki (Nurhasanah, 2008).

Ketua Relawan Desa Jelok menjelaskan bahwa banyak warganya yang masih mengalami trauma akibat tanah longsor seperti ketakutan ketika terjadi hujan ataupun suara angin kencang. Dampak trauma di Desa Jelok lebih banyak dialami oleh wanita yang tinggal di desa 
tersebut. Hal tersebut terjadi karena minimnya trauma healing yang dilakukan pada wanita korban bencana tanah longsor. Berdasarkan hasil wawancara dengan ibu-ibu yang mengalami bencana tanah longsor, mereka mengeluhkan masih merasa ketakutan ketika keadaan di sekitar lingkungannya mendung yang disertai hujan dengan angin kencang. Selain itu, adanya bencana membuat mereka merasa tidak nyaman dalam beraktivitas sehari-hari dan tidak dapat tidur dengan tenang, karena mereka merasa tidak aman berada di daerah yang rawan terjadi tanah longsor.

Perlindungan korban bencana alam tidak hanya terkait dengan penyembuhan fisik, tetapi yang tidak kalah penting adalah penanganan luka trauma akibat bencana. Trauma tersebut harus segera ditangani karena orang yang mengalami trauma menjadikan dirinya juga mengalami penurunan kualitas hidup (Hapsari, 2015). Pernyataan tersebut didukung oleh hasil penelitian Nygaard \& Heir (2012) menunjukkan bahwa kondisi trauma memiliki hubungan negatif dengan kualitas hidup yang baik pada korban bencana alam tsunami di Norwegia dan Asia Tenggara. Seseorang yang mengalami bencana alam akan mengalami perubahan berupa adanya persepsi positif menjadi negatif dalam rasa harga diri dan kebermaknaan hidup. Hal tersebut menjadikan adanya penurunan kualitas hidup pada korban bencana alam.

Safarino \& Smith (Sarafino \& Smith, 2014) mengartikan bahwa kualitas hidup adalah penilaian individu tentang peningkatan yang dialaminya selama hidup berkaitan dengan kemampuan dalam beraktivitas, energi atau ketidaknyamanan, perasaan positif dan negatif kontrol pribadi, hubungan interpersonal, kenyamanan beraktivitas, materi pertumbuhan pribadi dan intelektual. Secara umum kualitas hidup mencakup semua area kehidupan yaitu komponen lingkungan, material, komponen fisik, dan sosial (Dewi, 2014). Kualitas hidup akan mengalami penurunan apabila aspek-aspek dari kualitas hidup itu sendiri masih kurang terpenuhi (Karangora, Yudiarso, \& Mazdafiah, 2012). Jika seseorang mencapai kualitas hidup yang rendah, maka kehidupan individu tersebut mengarah pada keadaan tidak sejahtera (illbeing) (Das, 2008).

Sadli (Sadli, 2010) menjelaskan bahwa terdapat domain-domain yang merupakan bagian penting untuk mengetahui kualitas hidup individu. Domain-domain tersebut adalah kesehatan fisik, psikologis, sosial, dan lingkungan. Kualitas hidup pada masyarakat yang mengalami 
bencana alam lebih banyak dipengaruhi oleh tingkat depresi, interaksi sosial, dan jenis kelamin yang menunjukkan bahwa perempuan lebih banyak mengalami kualitas hidup yang rendah dibandingkan dengan laki-laki (Nurhasanah, 2008). Peningkatan kualitas hidup pada korban bencana merupakan hal yang penting agar masyarakat menjadi lebih sejahtera meskipun dalam bayang-bayang potensi dan kemungkinan bencana (Yulaelawati, 2008).

Permasalahan yang dialami ibu-ibu yang mengalami bencana tanah longsor di Purworejo menunjukkan adanya penurunan kualitas hidup pada wanita yang menjadi korban bencana alam. Disamping itu, kondisi ekonomi mereka termasuk rendah. Hal tersebut mempengaruhi kualitas hidup mereka karena kondisi ekonomi dapat mempengaruhi kualitas hidup seseorang (Aprillia \& Puspitasari, 2007). Mereka juga memiliki kondisi kesehatan yang kurang baik karena sulitnya mendapatkan sarana kesehatan pasca terjadi tanah longsor. Kondisi kesehatan merupakan hal yang dapat mempengaruhi kualitas hidup (Handayani \& Dewi, 2016). Selain itu, wanita biasanya memiliki kualitas hidup yang lebih buruk dibanding laki-laki (Chou dkk., 2007).

Wanita merupakan kelompok rentan yang perlu diberikan penanganan khusus di dalam situasi bencana. Kerentanan wanita berakar kuat pada ketidaksetaraan gender yang membatasi mobilitas mereka, membuat mereka kurang mampu melepaskan diri dari bahaya dan melindungi diri dari konsekuensi bencana yang dialaminya (Bizzarri, 2012). Kerentanan tersebut juga berkaitan erat dengan optimisme dan harapan untuk bangkit kembali dari masalah (Primardi \& Hadjam, 2011). Selain itu, mereka memiliki strategi koping yang rendah dalam situasi bencana. Hal tersebut juga dapat mempengaruhi kualitas hidup mereka (Rubbyana, 2012).

Beberapa intervensi yang telah diteliti dan berdampak positif untuk meningkatkan kualitas hidup antara lain dengan terapi relaksasi. Penelitian Sulistyarini (Sulistyarini, 2013) menunjukkan bahwa terapi relaksasi dapat menurunkan tekanan darah dan meningkatkan kualitas hidup penderita hipertensi. Hasil penelitian menunjukkan adanya penurunan tekanan darah sistolik yang signifikan dan tekanan darah diastolik pada kelompok eksperimen dibandingkan kelompok kontrol. Selain itu, terdapat penelitian lain seperti hasil penelitian Putri (Putri, 2016) yang menunjukkan bahwa pelatihan kebersyukuran memberikan perubahan 
yang positif pada kualitas hidup lansia yakni derajat kesehatan lansia semakin baik, lebih semangat dan ikhlas dalam menjalani masa tua, dan lebih bersyukur atas apa yang dimiliki. Adapun Penelitian yang dilakukan oleh Wardiyah (Wardiyah, 2013) yang memberikan group positive psychoteraphy pada remaja yang memiliki orang tua bekerja sebagai TKI (Tenaga Kerja Indonesia) menunjukkan hasil bahwa group positive psychoteraphy dapat meningkatkan psychological well-being pada remaja. Jika seseorang memiliki psychological well-being yang tinggi, maka kehidupan individu tersebut mengarah pada kualitas hidup yang baik (Brown, Bowling, \& Flynn, 2004).

Penelitian-penelitian tersebut menunjukkan bahwa penanganan psikologis untuk meningkatkan kualitas hidup sangat beragam, salah satu penanganan yang dapat digunakan adalah dengan Spiritual Emotional Freedom Technique (SEFT). SEFT menjelaskan bahwa penyebab segala macam emosi negatif adalah terganggunya sistem energi tubuh. Oleh karena itu, solusinya adalah dengan menetralisir gangguan energi itu dengan SEFT. Aliran energi yang tersumbat di beberapa titk kunci tubuh harus dibebaskan hingga mengalir lagi dengan lancar. Cara membebaskannya adalah dengan mengetuk ringan dengan dua ujung jari (tapping) di bagian tubuh tertentu, sambil mengucapkan kalimat yang berupa doa. Doa berperan sangat penting untuk penyembuhan yang telah terbukti secara ilmiah (Zainuddin, 2006).

SEFT adalah suatu teknik yang menggabungkan antara spiritualitas berupa doa, keikhlasan, dan kepasrahan, dengan Emotional Freedom Tehnique (EFT) yang merupakan seperangkat prinsip dan tehnik memanfaatkan sistem energi tubuh untuk memperbaiki kondisi pikiran, emosi, dan perilaku melalui tiga teknik sederhana yaitu set-up, tune-up, dan tapping (Zainuddin, 2006).

Hasil penelitian Feinstein (Feinstein, 2008) menunjukkan bahwa EFT dapat mengatasi trauma pada korban bencana alam di Kongo, Guatemala, Indonesia, Kenya, Kosovo, Kuwait, Moldavia, Nairobi, Rwanda, Afrika Selatan, Tanzania, Thailand, dan Amerika Serikat. EFT juga dapat digunakan untuk meningkatkan kualitas hidup pada orang yang mengalami sakit kepala kronis (Bougea dkk., 2013). Energi psikologi dilakukan dengan memunculkan kewaspadaan yang tinggi berupa bayangan pikiran, cerita, dan pengalaman yang berhubungan dengan ingatan kejadian traumatis atau situasi yang mengancam. Hal terunik dari energi psikologi 
adalah penghapusan ingatan tentang kejadian traumatis difasilitasi oleh tiga hal berikut yaitu adanya stimulasi manual dari akupuntur yang berhubungan dengan hal yang diyakini, mengirim sinyal ke amigdala dan struktur otak lainnya, serta mengurangi kewaspadaan yang berlebihan dengan cepat.

Penggunaan tapping dalam EFT secara signifikan dapat menurunkan tingkat Kortisol dalam tubuh. Selanjutnya dalam proses tapping, dilakukan juga beberapa gerakan yang disebut dengan the nine gamut procedure yaitu sembilan gerakan untuk merangsang otak yang dilakukan bersamaan dengan mengetuk ringan pada titik gamut spot yang biasa dikenal dengan istilah Eye Movement Desensitization and Reprocessing (EMDR) (Church, Yount, \& Brooks, 2012). EFT pun pernah digunakan oleh Church (Church, 2009) untuk merekonstruksi kognitif dan terapi exposure untuk mengatasi PTSD pada veteran yang telah mengalami pertempuran. Hal tersebut sejalan dengan penelitian Karatzi (Karatzias dkk., 2011) yang menunjukkan bahwa EFT dan EMDR efektif dalam mengatasi PTSD.

Menurut (Zainuddin, 2006), EFT akan semakin efektif apabila digabungkan dengan kekuatan doa dan spiritualitas. Pendapat Zainuddin didukung oleh hasil penelitian yang dilakukan oleh seorang dokter ahli penyakit dalam, Dossey yang melakukan penelitian ekstensif tentang efek doa terhadap kesembuhan pasien. Inti pesan yang disampaikan Dossey adalah bahwa doa dan spiritual, terbukti dalam penelitian ilmiah memiliki kekuatan yang sama besar dengan pengobatan dan pembedahan.

Penelitian Ulfah (Ulfa, 2013) menunjukkan bahwa SEFT dapat menurunkan Gangguan Stres Pasca Trauma pada remaja yang menjadi korban erupsi Gunung Merapi. Semua peserta merasa lebih tenang, rileks, dan nyaman setelah melakukan SEFT dengan tiga teknik sederhana yaitu set-up, tune-in, dan tapping sehingga perasaan takut, sedih, gelisah, trauma akibat kejadian erupsi Gunung Merapi menjadi berkurang dan seluruh peserta dapat melakukan SEFT secara mandiri setelah dipandu oleh terapis SEFT. SEFT juga dapat digunakan untuk mengatasi masalah fisik, contohnya seperti penelitian yang dilakukan oleh Hakam (Hariyati, Yetti, \& Hakam, 2009), menunjukan bahwa kombinasi SEFT dengan terapi analgesik lebih efektif dalam menurunkan rasa nyeri pada pasien kanker dibandingkan hanya terapi analgesik saja. Dampak-dampak psikologis dari penyakit fisik pun dapat diatasi dengan SEFT. Penelitian 
Bakara, Ibrahim, \& Sriati (Bakara, Ibrahim, \& Sriati, 2013) menunjukkan bahwa SEFT dapat mengurangi gejala depresi, kecemasan dan stress pada pasein Sindrom Koroner Akut.

Maka dari itu, perlu adanya intervensi untuk meningkatkan kualitas hidup pada wanita yang menjadi korban bencana tanah longsor. Salah satu penanganan yang dapat digunakan untuk meningkatkan kualitas hidup adalah dengan intervensi Spiritual Emotional Freedom Tehnique (SEFT). Penelitian yang akan dilakukan terkait dengan usaha peningkatan kualitas hidup pada wanita yang menjadi korban tanah longsor di Purworejo. Keluhan mereka adalah masih merasa ketakutan ketika keadaan disekitar lingkungannya gelap yang disertai hujan deras dan angin kencang. Tujuan penelitian ini adalah untuk mengetahui pengaruh Spiritual Emotional Freedom Technique dalam meningkatkan kualitas hidup pada wanita yang mengalami bencana tanah longsor di Purworejo, sehingga diharapkan peneliti dapat membantu memecahkan masalah wanita yang mengalami penurunan kualitas hidup karena bencana tanah longsor.

\section{Metode}

Variabel dalam penelitian ini terdiri dari dua variabel, yaitu variabel tergantung yang artinya variabel yang berubah jika berhubungan dengan variabel bebas, dan variabel bebas

yang artinya variabel yang dimanipulasi untuk dipelajari efeknya pada variabel-variabel lain (Latipun, 2015). Variabel tergantung dalam penelitian ini adalah kualitas hidup dan variabel bebasnya adalah SEFT.

Subjek Penelitian

Subjek penelitian dalam penelitian ini adalah enam orang wanita dewasa di Purworejo dengan kriteria berusia 20 sampai 40 tahun, mengalami bencana longsor di tempat kejadian bencana, memiliki kualitas hidup yang rendah berdasarkan hasil kategorisasi skala WHOQOLBREF, beragama Islam, mampu berkomunikasi dan kooperatif, tidak mengalami gangguan mental berat, dan bersedia menjadi subjek dalam penelitian ini yang dibuktikan dengan pengisian informed consent.

Norma dalam skala WHOQOL-BREEF yang digunakan dalam pre-test terbagi dalam lima kategori yang dapat dilihat dari perolehan tranformed scores pada masing-masing subjek. Kelima 
kategori tersebut adalah kualitas hidup sangat buruk dengan perolehan skor antara 0-20, kualitas hidup buruk dengan perolehan skor antara 21-40, kualitas hidup sedang dengan perolehan skor antara 41-60, kualitas hidup baik dengan perolehan skor antara 61-80, dan kualitas hidup sangat baik dengan perolehan skor antara 81-100.

Metode Pengumpulan Data

1. Skala Kualitas Hidup

Skala yang digunakan umtuk mengukur tingkat kualitas hidup pada wanita yang mengalami bencana alam tanah longsor di Purworejo adalah skala yang diadaptasi dari The World Health Organization Quality of Life (WHOQOL) -BREF (Salim, Sudharma, Kusumaratna, \& Hidayat, 2016). WHOQOL adalah suatu alat ukur berupa skala yang dinilai dari domain kualitas hidup yaitu kesehatan fisik, aspek psikologis, hubungan sosial, dan lingkungan. Peneliti menggunakan Skala The World Health Organization Quality of Life (WHOQOL)-BREF (Salim dkk., 2016), jadi peneliti tidak menyusun sendiri skala tersebut.

\section{Wawancara}

Wawancara dilakukan untuk mendapatkan data secara kualitatif mengenai kondisi subjek, perasaan dan sebagai salah satu data tambahan mengenai efektivitas dari terapi yang diberikan. Wawancara dilakukan dengan subjek dan significant others.

\section{Observasi}

Observasi dilakukan untuk memperoleh data alami yang mendukung data-data yang sudah ada dari hasil penyebaran skala dan wawancara. Observasi ini dilakukan selama proses terapi.

\section{Lembar kerja}

Pada lembar kerja, subjek diminta menuliskan bagaimana perasaan yang muncul terkait dengan rasa sakit yang dirasakan sebelum dilakukan terapi SEFT dan setelah dilakukan terapi SEFT. Selanjutnya subjek diminta menuliskan kalimat set-up yang digunakan selama melakukan terapi SEFT serta menuliskan berapa skala dari perasaan yang muncul sebelum dilakukan terapi SEFT dan setelah dilakukan terapi SEFT.

5. Lembar Evaluasi 
Pada lembar evaluasi, subjek diminta untuk memberikan penilaian terhadap pelaksanaan pelatihan yang telah dilakukan. Lembar evaluasi ini diisi oleh subjek setelah berakhirnya semua sesi pelatihan. Lembar evaluasi ini mencakup evaluasi pelaksanaan terapi SEFT secara umum, proses terapi, dan SEFTer yang memberikan terapi.

\section{Modul Spiritual Emotional Freedom Technique}

Modul dalam penelitian ini diadaptasi dari modul Spiritual Emotional Freedom Technique (SEFT) yang disusun oleh Rahmah (2016). Program ini terdiri dari tiga sesi yang berlangsung selama dua sampai tiga jam. Program ini akan dipandu oleh seorang fasilitator dan dibantu oleh seorang co-fasilitator. Fasilitator dalam penelitian ini adalah psikolog klinis yang berkompeten dalam melakukan Spiritual Emotional Freedom Technique (SEFT).

\section{Desain Eksperimen}

Penelitian menggunakan desain kuasi eksperimen dengan model rancangan penelitian yang akan digunakan adalah one grup pretest - posttest design. Desain ini bertujuan untuk melihat efek suatu perlakuan terhadap kelompok eksperimen, sehingga hasil perlakuan dapat diketahui lebih akurat karena dapat membandingkan dengan keadaan sebelum diberi perlakuan. Penelitian dilakukan pada satu kelompok yaitu kelompok eksperimen yang berjumlah enam orang yang akan mendapatkan perlakuan berupa intervensi SEFT. Adapun bentuk rancangan tersebut di bawah ini :

Tabel 1

Desain Eksperimen

\begin{tabular}{ccccc}
\hline Kelompok & Pretest & Perlakuan & Posttest & Follow up \\
\hline KE NR & Y1 & $\mathrm{X}$ & $\mathrm{Y} 2$ & $\mathrm{Y} 3$ \\
\hline
\end{tabular}

\section{Keterangan}

KE : Kelompok eksperimen non random

Y1 : Pengukuran sebelum perlakuan

X : Perlakuan

Y2 : Pengukuran setelah perlakuan

Y3 : Follow up 


\section{Prosedur Eksperimen}

Tabel 2

Prosedur SEFT (Spiritual Emotional Freedom Technique)

\begin{tabular}{|c|c|c|c|c|}
\hline \multirow[b]{2}{*}{ Tujuan } & \multirow[b]{2}{*}{ Sesi } & \multirow[b]{2}{*}{ Kegiatan } & \multicolumn{2}{|c|}{ Waktu } \\
\hline & & & Pertemuan & Durasi \\
\hline $\begin{array}{l}\text { - Membangun suasana akrab } \\
\text { antar peserta } \\
\text { - Peserta mengetahui tujuan } \\
\text { kegiatan pelatihan secara } \\
\text { keseluruhan } \\
\text { - Peserta memiliki kemauan } \\
\text { untuk mengikuti pelatihan } \\
\text { secara keseluruhan }\end{array}$ & $\begin{array}{l}\text { Perkenalan dan } \\
\text { kontrak belajar }\end{array}$ & $\begin{array}{l}\text { - Perkenalan pelatih, SEFTer } \\
\text { dan observer } \\
\text { - Penjelasan tujuan } \\
\text { pelatihan secara umum } \\
\text { - Menulis harapan } \\
\text { - Informed Consent }\end{array}$ & I & 20 menit \\
\hline $\begin{array}{l}\text { - Peserta mengenal terapi SEFT } \\
\text { beserta manfaatnya } \\
\text { - Peserta memahami tentang } \\
\text { terapi SEFT }\end{array}$ & $\begin{array}{l}\text { Pengenalan } \\
\text { Terapi SEFT }\end{array}$ & $\begin{array}{l}\text { - Penjelasan terkait terapi } \\
\text { SEFT } \\
\text { - Diskusi Tanya jawab }\end{array}$ & & 50 menit \\
\hline $\begin{array}{l}\text { - Membantu } \\
\text { mengendalikan pikiran dan } \\
\text { emosi agar tidak mudah } \\
\text { terganggu oleh keadaan } \\
\text { negatif. } \\
\text { - Membantu peserta untuk } \\
\text { membangkitkan harapan, } \\
\text { rasa percaya diri dan } \\
\text { kekebalan tubuhnya } \\
\text { meningkat sehingga } \\
\text { mempercepat dalam } \\
\text { menyelesaikan permasalahan } \\
\text { fisik maupun psikis. } \\
\text { - Membantu peserta lebih } \\
\text { ikhlas dalam kehidupannya. } \\
\text { - Membantu peserta } \\
\text { meningkatkan kinerja dan } \\
\text { prestasi. } \\
\text { - Peserta memiliki } \\
\text { keterampilan menerapkan } \\
\text { terapi SEFT versi singkat } \\
\text { dalam kehidupan sehari-hari. }\end{array}$ & $\begin{array}{lr}\text { Praktek } & \text { terapi } \\
\text { SEFT } & \text { versi } \\
\text { singkat } & \end{array}$ & $\begin{array}{l}\text { Praktek terapi SEFTyaitu : } \\
\text { Set-up, tune-in,dan tapping } \\
\text { untuk keluhan fisik dan } \\
\text { emosi. }\end{array}$ & & 90 menit \\
\hline $\begin{array}{l}\text { - Peserta lebih memahami dan } \\
\text { mampu menetapkan tujuan } \\
\text { dari pelatihan terapi SEFT } \\
\text { - Peserta mampu } \\
\text { mempraktekkan terapi SEFT }\end{array}$ & $\begin{array}{l}\text { Refleksi dan } \\
\text { Tugas rumah }\end{array}$ & $\begin{array}{l}\text { - Refleksi perasaan } \\
\text { - Pemberian tugas rumah }\end{array}$ & & 20 menit \\
\hline
\end{tabular}


versi singkat secara mandiri

\begin{tabular}{|c|c|c|c|c|}
\hline \multirow[b]{2}{*}{ Tujuan } & \multirow[b]{2}{*}{ Sesi } & \multirow[b]{2}{*}{ Kegiatan } & \multicolumn{2}{|c|}{ Waktu } \\
\hline & & & Pertemuan & Durasi \\
\hline $\begin{array}{l}\text { Evaluasi terapi SEFT versi } \\
\text { singkat yang telah dilakukan } \\
\text { masing-masing peserta secara } \\
\text { mandiri di rumah }\end{array}$ & $\begin{array}{l}\text { Pengecekan } \\
\text { tugas rumah }\end{array}$ & $\begin{array}{r}\text { Mengecek tugas rumah } \\
\text { peserta }\end{array}$ & II & 30 menit \\
\hline $\begin{array}{l}\text { - Membantu peserta } \\
\text { mengendalikan pikiran dan } \\
\text { emosi agar tidak mudah } \\
\text { terganggu oleh keadaan } \\
\text { negatif. } \\
\text { - Membantu peserta untuk } \\
\text { membangkitkan harapan, } \\
\text { rasa percaya diri dan } \\
\text { kekebalan tubuhnya } \\
\text { meningkat sehingga } \\
\text { mempercepat dalam } \\
\text { menyelesaikan permasalahan } \\
\text { fisik maupun psikis. } \\
\text { - Membantu peserta lebih } \\
\text { ikhlas dalam kehidupannya. } \\
\text { - Membantu peserta } \\
\text { meningkatkan kinerja dan } \\
\text { prestasi. } \\
\text { - Peserta memiliki } \\
\text { keterampilan menerapkan } \\
\text { SEFT versi lengkap dalam } \\
\text { kehidupan sehari-hari. }\end{array}$ & $\begin{array}{lr}\text { Praktek } & \text { terapi } \\
\text { SEFT } & \text { versi } \\
\text { lengkap } & \end{array}$ & $\begin{array}{l}\text { Praktek terapi SEFT yaitu : } \\
\text { Set-up, tune-in,dan tapping } \\
\text { untuk keluhan fisik dan } \\
\text { emosi. }\end{array}$ & & 90 menit \\
\hline $\begin{array}{l}\text { - Memonitor pelaksanaan } \\
\text { pelatihan sebagai bahan } \\
\text { masukan untuk pelatihan } \\
\text { selanjutnya }\end{array}$ & $\begin{array}{r}\text { Evaluasi dan } \\
\text { pengisian } \\
\text { kuesioner }\end{array}$ & $\begin{array}{l}\text { - Mengisi lembar evaluasi } \\
\text { - Peserta mengisi skala } \\
\text { kualitas hidup }\end{array}$ & & 30 menit \\
\hline $\begin{array}{l}\text { - Sebagai proses evaluasi } \\
\text { pelatihan bagi SEFTer } \\
\text { maupun peneliti. } \\
\text { - Mengetahui tingkat kualitas } \\
\text { hidup pada peserta }\end{array}$ & & & & \\
\hline $\begin{array}{l}\text { - Mengetahui efektivitasterapi } \\
\text { SEFT dalam praktek } \\
\text { kehidupan peserta sehari- } \\
\text { hari. }\end{array}$ & Follow Up & - Refleksi dan diskusi & III & 60 menit \\
\hline
\end{tabular}


- Mengetahui tingkat kualitas hidup pada peserta

- Memperoleh kesimpulan dari pelatihan yang sudah dilaksanakan.

\begin{tabular}{|c|c|c|}
\hline Terminasi & $\begin{array}{l}\text { - Peserta mengis } \\
\text { kualitas hidup } \\
\text { - Wawancara } \\
\text { penutupan }\end{array}$ & 20 menit \\
\hline
\end{tabular}

\section{Validitas dan Reliabilitas Alat Ukur}

Skala kualitas hidup dalam penelitian ini menggunakan instrumen kualitas hidup yang dibuat oleh WHO yaitu WHOQOL-BREF. Alat ukur WHOQOL-BREF adalah alat ukur yang valid (0.89-0.95) dan reliable (0.66-0.87), yang dilihat dari setiap dimensinya yaitu kesehatan fisik, aspek psikologis, hubungan sosial, dan lingkungan. Alat ukur ini telah diadaptasi ke berbagai bahasa, termasuk bahasa Indonesia untuk penelitian pada pemakai narkoba (V Wardhani, 2006).

Pengujian instrumen WHOQOL-BREEF oleh Sekarwiri (Sekarwiri, 2008) yang meneliti tentang kualitas hidup dengan sense of community pada warga Jakarta yang tinggal di daerah rawan banjir, menunjukkan hasil validitas sebesar 0,384-0,889, dengan rata-rata 0,603, sedangkan ujian reliabilitas dengan menggunakan Coefficient Alpha Cronbach diperoleh sebesar 0,902. Hasil uji validitas menunjukkan adanya hubungan yang signifikan antar setiap aitem dengan setiap skor dimensi yang memuat aitem tersebut. Pengujian tentang instrumen WHOQOL-BREF juga dilakukan oleh Salim dkk (Salim dkk., 2016) dengan tujuan menilai validitas dan reliabilitas WHOQOL-BREF sebagai instrument untuk mengukur kualitas hidup. Hasil penelitian menunjukkan distribusi skor setiap domain dari WHOQOL-BREF adalah simetris dan tidak didapatkan efek floor atau ceiling.

Hasil ini menunjukkan adanya korelasi yang positif dan tinggi antar skor dengan kata lain instrumen WHOQOL-BREF merupakan instrumen yang valid untuk mengukur kualitas hidup. Selain itu, penelitian ini juga menggunakan metode pengumpulan data dengan melakukan observasi, wawancara, lembar kerja, dan lembar evaluasi yang digunakan untuk mendapatkan data secara kualitatif mengenai kondisi subjek, perasaan, dan sebagai salah satu data tambahan mengenai efektivitas dari terapi yang diberikan. 


\begin{tabular}{|c|c|c|c|c|c|c|c|c|c|c|c|c|c|c|c|}
\hline \multirow{2}{*}{ Nama } & \multicolumn{3}{|c|}{ Domain 1} & \multicolumn{3}{|c|}{ Domain 2} & \multicolumn{3}{|c|}{ Domain 3} & \multicolumn{3}{|c|}{$\begin{array}{c}\text { Domain } \\
4\end{array}$} & \multicolumn{3}{|c|}{ Total } \\
\hline & $\begin{array}{l}\text { Pre- } \\
\text { Test }\end{array}$ & $\begin{array}{c}\text { Post- } \\
\text { Test }\end{array}$ & $\begin{array}{c}\text { Follow } \\
\text { Up }\end{array}$ & $\begin{array}{l}\text { Pre- } \\
\text { Test }\end{array}$ & $\begin{array}{l}\text { Post- } \\
\text { Test }\end{array}$ & $\begin{array}{c}\text { Follow } \\
\text { Up }\end{array}$ & $\begin{array}{l}\text { Pre- } \\
\text { Test }\end{array}$ & $\begin{array}{l}\text { Post- } \\
\text { Test }\end{array}$ & $\begin{array}{c}\text { Follow } \\
\text { Up }\end{array}$ & $\begin{array}{l}\text { Pre- } \\
\text { test }\end{array}$ & $\begin{array}{c}\text { Post- } \\
\text { Test }\end{array}$ & $\begin{array}{c}\text { Follow } \\
\text { up }\end{array}$ & $\begin{array}{l}\text { Pre- } \\
\text { test }\end{array}$ & $\begin{array}{l}\text { Post- } \\
\text { test }\end{array}$ & $\begin{array}{c}\text { Follow } \\
\text { up }\end{array}$ \\
\hline
\end{tabular}

\section{Analisis Data}

Metode analisis data yang digunakan dalam penelitian ini adalah analisis data kuantitatif. Metode yang akan digunakan dalam analisis kuantitatif adalah statistic nonparametric karena data dalam penelitian tidak terdistribusi secara normal, sedangkan teknik analisis statistik untuk menguji hipotesis menggunakan Uji Wilcoxon Signed Rank Test. Pada uji ini menggunakan sampel yang sama dan diberi perlakuan yang sama. Peneliti ingin membandingkan data pada saat pre-test, post-test, dan follow-up. Pengujian hipotesis dibantu menggunakan komputer program SPSS (Statistical Product E Service Solution) 16.0 for windows.

\section{H a s i 1}

Deskripsi penelitian yang diperoleh dari pre-test, post-test, dan follow-up dari skor skala kualitas hidup dapat dilihat pada table 3 berikut:

Tabel 3

Perbandingan Kategori Kualitas Hidup Kelompok Eksperimen 


\begin{tabular}{|c|c|c|c|c|c|c|c|c|c|c|c|c|c|c|c|}
\hline $\mathrm{KR}$ & $\begin{array}{c}17 \\
\text { buruk }\end{array}$ & $\begin{array}{c}27 \\
\text { baik }\end{array}$ & $\begin{array}{c}25 \\
\text { baik }\end{array}$ & $\begin{array}{c}14 \\
\text { buruk }\end{array}$ & $\begin{array}{c}25 \\
\text { sangat } \\
\text { baik }\end{array}$ & $\begin{array}{c}24 \\
\text { baik }\end{array}$ & $\begin{array}{c}11 \\
\text { Baik }\end{array}$ & $\begin{array}{c}11 \\
\text { baik }\end{array}$ & $\begin{array}{c}11 \\
\text { baik }\end{array}$ & $\begin{array}{c}11 \\
\text { sangat } \\
\text { buruk }\end{array}$ & $\begin{array}{c}27 \\
\text { baik }\end{array}$ & $\begin{array}{c}26 \\
\text { sedang }\end{array}$ & 53 & 90 & 86 \\
\hline SR & $\begin{array}{c}17 \\
\text { buruk }\end{array}$ & $\begin{array}{c}26 \\
\text { baik }\end{array}$ & $\begin{array}{c}25 \\
\text { baik }\end{array}$ & $\begin{array}{c}12 \\
\text { buruk }\end{array}$ & $\begin{array}{c}18 \\
\text { sedang }\end{array}$ & $\begin{array}{c}19 \\
\text { Sedang }\end{array}$ & $\begin{array}{c}9 \\
\text { Sedang }\end{array}$ & $\begin{array}{c}11 \\
\text { baik }\end{array}$ & $\begin{array}{c}11 \\
\text { baik }\end{array}$ & $\begin{array}{c}17 \\
\text { buruk }\end{array}$ & $\begin{array}{c}24 \\
\text { sedang }\end{array}$ & $\begin{array}{c}23 \\
\text { sedang }\end{array}$ & 55 & 79 & 78 \\
\hline YL & $\begin{array}{c}16 \\
\text { buruk }\end{array}$ & $\begin{array}{c}25 \\
\text { baik }\end{array}$ & $\begin{array}{c}23 \\
\text { sedang }\end{array}$ & $\begin{array}{c}13 \\
\text { buruk }\end{array}$ & $\begin{array}{c}21 \\
\text { Baik }\end{array}$ & $\begin{array}{c}19 \\
\text { Sedang }\end{array}$ & $\begin{array}{c}8 \\
\text { Sedang }\end{array}$ & $\begin{array}{c}11 \\
\text { baik }\end{array}$ & $\begin{array}{c}11 \\
\text { baik }\end{array}$ & $\begin{array}{c}15 \\
\text { buruk }\end{array}$ & $\begin{array}{c}30 \\
\text { baik }\end{array}$ & $\begin{array}{c}25 \\
\text { sedang }\end{array}$ & 52 & 87 & 78 \\
\hline SP & $\begin{array}{c}15 \\
\text { buruk }\end{array}$ & $\begin{array}{c}26 \\
\text { baik }\end{array}$ & $\begin{array}{c}26 \\
\text { baik }\end{array}$ & $\begin{array}{c}10 \\
\text { sangat } \\
\text { buruk }\end{array}$ & $\begin{array}{c}21 \\
\text { Baik }\end{array}$ & $\begin{array}{c}20 \\
\text { Sedang }\end{array}$ & $\begin{array}{c}10 \\
\text { Sedang }\end{array}$ & $\begin{array}{c}11 \\
\text { baik }\end{array}$ & $\begin{array}{c}11 \\
\text { baik }\end{array}$ & $\begin{array}{c}16 \\
\text { buruk }\end{array}$ & $\begin{array}{c}25 \\
\text { sedang }\end{array}$ & $\begin{array}{c}24 \\
\text { sedang }\end{array}$ & 51 & 83 & 81 \\
\hline NG & $\begin{array}{c}12 \\
\text { sangat } \\
\text { buruk }\end{array}$ & $\begin{array}{c}27 \\
\text { baik }\end{array}$ & $\begin{array}{c}24 \\
\text { baik }\end{array}$ & $\begin{array}{c}11 \\
\text { sangat } \\
\text { buruk }\end{array}$ & $\begin{array}{c}21 \\
\text { Baik }\end{array}$ & $\begin{array}{c}18 \\
\text { Sedang }\end{array}$ & $\begin{array}{c}10 \\
\text { Sedang }\end{array}$ & $\begin{array}{c}11 \\
\text { baik }\end{array}$ & $\begin{array}{c}10 \\
\text { sedang }\end{array}$ & $\begin{array}{c}13 \\
\text { sangat } \\
\text { buruk }\end{array}$ & $\begin{array}{c}23 \\
\text { sedang }\end{array}$ & $\begin{array}{c}21 \\
\text { sedang }\end{array}$ & 46 & 82 & 73 \\
\hline $\mathrm{RZ}$ & $\begin{array}{c}17 \\
\text { buruk }\end{array}$ & $\begin{array}{c}26 \\
\text { baik }\end{array}$ & $\begin{array}{c}26 \\
\text { baik }\end{array}$ & $\begin{array}{c}15 \\
\text { buruk }\end{array}$ & $\begin{array}{c}23 \\
\text { Baik }\end{array}$ & $\begin{array}{c}23 \\
\text { Baik }\end{array}$ & $\begin{array}{c}10 \\
\text { Sedang }\end{array}$ & $\begin{array}{c}12 \\
\text { baik }\end{array}$ & $\begin{array}{c}11 \\
\text { baik }\end{array}$ & $\begin{array}{c}17 \\
\text { buruk }\end{array}$ & $\begin{array}{c}28 \\
\text { baik }\end{array}$ & $\begin{array}{c}27 \\
\text { sedang }\end{array}$ & 59 & 88 & 87 \\
\hline
\end{tabular}

Berdasarkan data sebelumnya menunjukkan bahwa terjadi peningkatan skor kualitas hidup, baik pada masing-masing domain maupun secara keseluruhan yang dilihat dari pre-test, post-test, dan follow-up pada semua subjek penelitian.

\section{Analisis Kuantitatif}

Analisis kuantitatif yang digunakan dalam penelitian ini menggunakan metode statistik non parametrik dengan teknik Wilcoxon Signed Rank Test. Peneliti ingin membandingkan data pre-post dan post-follow. Deskripsi hasil analisis penelitian yang diperoleh dari pre-test dan posttest dari skor skala kualitas hidup pada masing-masing domain dan secara keseluruhan dapat dilihat pada tabel 4 berikut:

Tabel 4

Hasil Analisis Pre-Test dan Post-Test Skor Kualitas Hidup

\begin{tabular}{lccc}
\hline \multicolumn{1}{c}{ Domain } & Pre-test & Post-test & Asymp.Sig. (2-tailed) \\
\hline Kesehatan & 15,67 & 26,17 & 0,026 \\
Psikologis & 12,50 & 21,50 & 0,027 \\
Sosial & 9,67 & 11,17 & 0,041 \\
Lingkungan & 14,83 & 26,17 & 0,028 \\
\multicolumn{1}{c}{ Kualitas hidup keseluruhan } & 52,67 & 85,00 & 0,028 \\
\hline
\end{tabular}

Berdasarkan hasil di atas dapat disimpulkan bahwa terdapat perbedaan peningkatan tingkat kualitas hidup yang signifikan, baik pada masing-masing domain maupun secara 
keseluruhan antara sebelum dan setelah diberi perlakuan berupa SEFT. Berdasarkan hasil analisis kuantitatif yang telah dipaparkan maka dapat disimpulkan bahwa hipotesis penelitian ini diterima, yaitu adanya pengaruh Spiritual Emotional Freedom Technique (SEFT) terhadap peningkatan kualitas hidup pada wanita yang mengalami bencana tanah longsor di Purworejo.

Adapaun deskripsi hasil analisis penelitian yang diperoleh dari post-test dan follow-up dari skor skala kualitas hidup pada masing-masing domain dan secara keseluruhan dapat dilihat pada tabel berikut:

Tabel 5

Hasil Analisis Post-Test dan Follow-Up Skor Kualitas Hidup

\begin{tabular}{lccc}
\hline \multicolumn{1}{c}{ Domain } & Post-test & Follow-up & Asymp.Sig. (2-tailed) \\
\hline Kesehatan & 26,17 & 24,83 & 0,066 \\
Psikologis & 21,50 & 20,50 & 0,131 \\
Sosial & 11,17 & 10,83 & 0,157 \\
Lingkungan & 26,17 & 24,33 & 0,024 \\
$\quad$ Kualitas hidup keseluruhan & 85,00 & 80,50 & 0,027 \\
\hline
\end{tabular}

Berdasarkan hasil di atas dapat disimpulkan bahwa terdapat perbedaan kualitas hidup setelah dilakukan pelatihan SEFT antara post-test dengan follow-up. Hal tersebut menunjukkan adanya penurunan kualitas hidup setelah dua minggu diadakannya pelatihan SEFT pada wanita yang mengalami bencana tanah longsor di Purworejo. Meskipun demikian, terdapat peningkatan kualitas hidup antara pre-test dibandingkan dengan follow-up pada skor skala kualitas hidup yang dapat dilihat pada tabel berikut:

Tabel 6

Hasil Analisis Pre-Test dan Follow-Up Skor Kualitas Hidup

\begin{tabular}{lccc}
\hline \multicolumn{1}{c}{ Domain } & Pre-test & Post-test & Asymp.Sig. (2-tailed) \\
\hline Kesehatan & 15,67 & 24,83 & 0,027 \\
Psikologis & 12,50 & 20,50 & 0,027 \\
Sosial & 9,67 & 10,83 & 0,066 \\
Lingkungan & 14,83 & 24,33 & 0,027 \\
$\quad$ Kualitas hidup keseluruhan & 52,67 & 80,50 & 0,027 \\
\hline
\end{tabular}

Berdasarkan tabel 6 dapat disimpulkan terdapat pengaruh Spiritual Emotional Freedom Technique (SEFT) terhadap peningkatan kualitas hidup pada wanita yang mengalami bencana tanah longsor di Purworejo. 


\section{Analisis Kualitatif}

Seluruh subjek merasakan beberapa perubahan setelah mengikuti SEFT, di antaranya rasa cemas terhadap terjadinya tanah longsor kembali mulai berkurang. Sebelum mendapatkan terapi SEFT, seluruh peserta merasa ketakutan apabila terjadi hujan lebat dan angin kencang karena teringat kembali akan kejadian sewaktu terjadi tanah longsor. Seluruh subjek juga merasa lebih nyaman dan rileks dalam beraktivitas sehari-hari. Beberapa peserta memiliki aktivitas di luar rumah, seperti mencari kayu di hutan dan batu untuk membantu tetangga lain dan untuk memenuhi kebutuhan sehari-hari. Mereka merasa cemas ketika berada di luar rumah sebelum mendapatkan SEFT. Selain itu, ada dua orang peserta yang memiliki permasalahan dalam rumah tangganya. Setelah mendapatkan terapi SEFT, dua peserta tersebut merasa lebih tenang ketika menghadapi permasalahan tersebut.

\section{Pembahasan}

Hasil penelitian menunjukkan bahwa terdapat peningkatan tingkat kualitas hidup yang signifikan, baik pada masing-masing domain maupun secara keseluruhan antara sebelum dan setelah diberi perlakuan berupa SEFT. Berdasarkan hasil kuantitatif uji Wilcoxon Signed Rank Test antara pre-test dengan post-test menunjukkan bahwa taraf signifikansi sebesar 0,026 $<0,05$ untuk domain kesehatan, 0,027 < 0,05 untuk domain psikologis, 0,041 < 0,05 untuk domain sosial, $0,028<0,05$ untuk domain lingkungan. dan untuk keseluruhan domain taraf signifikansi sebesar 0,028 < 0,05. Sedangkan Uji Wilcoxon Signed Rank Test antara post-test dengan follow-up menunjukkan bahwa taraf signifikansi sebesar 0,066 > 0,05 untuk domain kesehatan, 0,131< 0,05 untuk domain psikologis, 0,157 < 0,05 untuk domain sosial, 0,024 < 0,05 untuk domain lingkungan, dan untuk keseluruhan domain taraf signifikansi sebesar 0,027<0,05.

Hasil penelitian ini menunjukkan bahwa tingkat kualitas hidup setelah diberikan terapi SEFT lebih tinggi daripada sebelum diberikan terapi SEFT. Selain itu, seluruh subjek juga merasakan beberapa perubahan setelah mengikuti SEFT, diantaranya rasa cemas terhadap terjadinya tanah longsor kembali mulai berkurang, merasa lebih nyaman dan rileks dalam beraktivitas sehari-hari, dan merasa lebih tenang ketika terdapat permasalahan dalam keluarga. 
Berdasarkan hasil penelitian ini dapat disimpulkan bahwa terapi SEFT dapat meningkatkan kualitas hidup pada wanita yang mengalami bencana tanah longsor di Purworejo.

Mardiyono, Songwathana, \& Petpichetchian (Mardiyono, Songwathana, \& Petpichetchian, 2011) dalam penelitiannya mengatakan bahwa intervensi spiritual merupakan intervensi perawatan yang berdasarkan pada prinsip islam mencangkup tata pelaksanaan secara islam seperti berdoa, pembacaan Al-Quran, berzikir, berpuasa, beramal, mengikuti sunnah nabi, dan memodifikasi metode islam untuk menyeimbangkan dan memadukan antara tubuh, pikiran, dan motivasi pada pasien. SEFT merupakan salah satu bentuk intervensi spiritual berupa doa yang dilakukan pada waktu set-up, yang dapat mengurangi permasalahan individu, kecemasan, dan dapat meningkatkan kontrol diri. Teknik tune-in dalam EFT maupun SEFT dilakukan dengan memfokuskan pikiran pada rasa sakit dengan tujuan untuk memusatkan pikiran subjek terkait pada rasa sakit yang dialami. Penelitian Kimbrough, Magyari, Langenberg, Chesney, \& Berman (Kimbrough, Magyari, Langenberg, Chesney, \& Berman, 2010)menyatakan bahwa mindfulness diiringi dengan penerimaan diri terhadap kejadian traumatis yang dialami dapat menurunkan gangguan stres paca trauma hyperarousal. Feinstein (Feinstein, 2008) mengungkapkan bahwa ketukan ringan atau tapping yang dilakukan untuk mengatasi gangguan psikologis dapat memberikan efek biokimia berupa teridentifikasinya neurotransmitter, endorpin, dan zat kimia lain dalam otak, sehingga dapat menurunkan tingkat kewaspadaan individu terhadap kejadian yang tidak menyenangkan.

Hasil penelitian ini mendukung penelitian terdahulu, Flint, Lammers, \& Mitnick (Flint, Lammers, \& Mitnick, 2006), yang mengungkapkan bahwa EFT merupakan metode yang sangat aman, mudah dan sederhana untuk dipelajari dan digunakan sebagai teknik yang dapat dilakukan oleh individu. Baker, Carrington, \& Putilin (Baker, Carrington, \& Putilin, 2009) menyatakan bahwa metode dengan prosedur EFT dapat dilakukan dalam waktu yang relatif singkat dengan efektif yang besar. Selain itu, hasil penelitian ini juga mendukung penelitian terdahulu yang dilakukan oleh Ulfah (Ulfa, 2013) dalam penanganan pada korban bencana dengan mengunggakan SEFT. Hasil penelitian Ulfah (Ulfa, 2013)menunjukkan bahwa SEFT dapat menurunkan PTSD pada remaja yang menjadi korban erupsi Gunung Merapi. Semua peserta merasa lebih tenang, rileks, dan nyaman setelah melakukan SEFT sehingga perasaan 
takut, sedih, gelisah, trauma akibat kejadian erupsi Gunung Merapi menjadi berkurang dan seluruh peserta dapat melakukan SEFT secara mandiri setelah dipandu oleh terapi SEFT. Selain itu, SEFT juga pernah dilakukan oleh Zainuddin (Zainuddin, 2006) pada saat membantu meringankan korban gempa bumi di Yogyakarta, Klaten dan beberapa kota di sekitarnya pada tahun 2006.

Mekanisme EFT secara psikologis menurut Haynes (Haynes, 2010) adalah pada saat melakukan EFT, terjadi peningkatan dari sumbu HPA (Hypothalamic Pituitary Adrenal), kemudian terjadi penghentian respon alarm dari sistem syaraf simpatis bergantian dengan respon relaksasi dalam sistem syaraf parasimpatis yang kemudian terjadi penurunan tingkat hormon kortisol dalam tubuh. Penelitian Lane (Lane, 2009) yang menunjukan bahwa menstimulasi secara manual pada titik akupuntur dapat meregulasi kortisol, menurunkan rasa sakit, memperlambat denyut jantung, menurunkan kecemasan, meregulasi sistem syaraf otonom dan dapat menciptakan rasa tenang. Sementara itu berdasarkan hasil penelitian Tantular (2015) dijelaskan secara fisiologis bahwa menstimulasi titik akupuntur juga dapat meningkatkan hormon endofrin yang dapat menghilangkan kecanduan akibat penyalahgunaan obat.

Hormon endorfin berfungsi untuk menghilangkan rasa sakit atau rasa nyeri dalam tubuh dan menimbulkan perasaan tenang setelah menghadapi perasaan traumatis. Selain itu, endorfin juga muncul untuk menghasilkan perasaan euforia. Secara umum perasaan euforia dapat terjadi ketika endorfin dilepaskan setelah melakukan olah raga seperti berlari, berenang, bersepeda, dan aerobik (Doctor \& Shiromoto, 2010). Demikian juga yang dirasakan subjek saat melakukan SEFT, maka hormon stres yang pada awalnya meningkat yaitu kortisol, epinefrin, dan norepinefrin yang dikeluarkan oleh kelenjar adrenal, kemudian dapat menurun setelah melakuan SEFT disertai dengan pelepasan hormon endorfin yang dapat mengatasi rasa nyeri (rasa sakit) yang dialami sehingga dengan demikian subjek yang melakukan SEFT akan merasa lebih tenang, lebih nyaman dan rileks setelah melakukan SEFT.

Hasil interview Stearns and Stearns (NurrieStearns \& NurrieStearns, 2013) terkait dengan penelitian Dossey tentang efek doa terhadap kesembuhan pasien yang dijelaskan secara rinci dalam The Power Of Prayer menunjukan bahwa doa merupakan salah satu metode 
penyembuhan yang efektif. Doa merupakan suatu pernyataan kesadaran yang ditandai dengan cinta, haru, dan kepedulian yang mendalam. Doa memberikan ketenangan pada individu dalam mengatasi setiap permasalahan hidup. Doa termasuk dalam set-up yang menyembuhkan dalam SEFT secara pisikologis, individu yang melakukan doa akan mengalami peningkatan hormon endorfin dalam tubuhnya sehingga cenderung merasa tenang dan tidak merasa sakit. Selain itu, unsur rasa syukur yang terkandung dalam doa mampu membuat seseorang berpikiran positif dalam menanggapi pengalaman emosional dan psikologis yang dialaminya (Vernon, Dillon, \& Steiner, 2009).

\section{Kesimpulan}

Berdasarkan hasil penelitian dapat disimpulkan bahwa SEFT (Spiritual Emotional Freedom Technique) terbukti dapat meningkatkan kualitas hidup pada wanita yang mengalami bencana tanah longsor di Purworejo, yang ditunjukkan dengan meningkatnya skor kualitas hidup pada domain kesehatan, psikologis, sosial, lingkungan, dan skor kualitas hidup secara keseluruhan, pada masing-masing peserta pelatihan setelah diberikan pelatihan SEFT. Seluruh subjek merasakan beberapa perubahan setelah mengikuti pelatihan SEFT, di antaranya merasa tenang apabila terjadi hujan deras dan angin kencang, bersemangat dalam beraktivitas tanpa khawatir akan terjadi longsor kembali, dan tidak sering terbayang kejadian sewaktu terjadi longsor.

\section{Kepustakaan}

Aprillia, N. I., \& Puspitasari, N. (2007). Faktor yang mempengaruhi tingkat kecemasan pada wanita perimenopause. The Indonesian Journal of Public Health, 4(1), 35-42.

Badan Nasional Penanggulangan Bencana. (2016). 24 tewas dan 26 orang hilang akibat banjir dan longsor di Jawa Tengah. Diambil 19 Januari 2017, dari https://bnpb.go.id/24-tewasdan-26-orang-hilang-akibat-banjir-dan-longsor-di-jawa-tengah.

Bakara, D. M., Ibrahim, K., \& Sriati, A. (2013). Pengaruh Spiritual Emotional Freedom Technique (SEFT) terhadap Tingkat Gejala Depresi, Kecemasan, dan Stres pada Pasien Sindrom Koroner Akut (SKA) Non Percutaneous Coronary Intervention (PCI). Abstrak, $1(1), 52-59$.

Baker, A., Carrington, P., \& Putilin, D. (2009). Theoretical and Methodological Problems in Research on Emotional Freedom Techniques (EFT) and Other Meridian Based Therapies. Psychology Journal, 6(2), 34-46.

Bizzarri, M. (2012). Protection of Vulnerable Groups in Natural and Man-Made Disasters. Dalam International Disaster Response Law (hlm. 381-414). Netherland: Springer. 
Bougea, A. M., Spandideas, N., Alexopoulos, E. C., Thomaides, T., Chrousos, G. P., \& Darviri, C. (2013). Effect of the emotional freedom technique on perceived stress, quality of life, and cortisol salivary levels in tension-type headache sufferers: a randomized controlled trial. Explore: The Journal of Science and Healing, 9(2), 91-99.

Brown, J., Bowling, A., \& Flynn, T. (2004). Models of quality of life: A taxonomy, overview and systematic review of the literature (Vol. 6, hlm. 46). European forum on population ageing research.

Chou, F. H.-C., Wu, H.-C., Chou, P., Su, C.-Y., Tsai, K.-Y., Chao, S.-S., ... Ou-Yang, W.-C. (2007). Epidemiologic psychiatric studies on post-disaster impact among Chi-Chi earthquake survivors in Yu-Chi, Taiwan. Psychiatry and Clinical Neurosciences, 61(4), 370-378.

Church, D. (2009). The effect of EFT (Emotional Freedom Techniques) on Athletic Performance: A randomized Controlled Blind Trial. The Open Sports Sciences Journal, 2(1), 94-99.

Church, D., Yount, G., \& Brooks, A. J. (2012). The effect of emotional freedom techniques on stress biochemistry: a randomized controlled trial. The Journal of nervous and mental disease, 200(10), 891-896.

Das, D. (2008). Urban quality of life: A case study of Guwahati. Social Indicators Research, 88(2), 297-310.

Dewi, S. R. (2014). Buku Ajar Keperawatan Gerontik. Yogyakarta: Deepublish.

Doctor, R. M., \& Shiromoto, F. N. (2010). The Encyclopedia of Trauma And Traumatic Stress Disorders. New York City: Facts On File, Inc.

Feinstein, D. (2008). Energy Psychology in Disaster Relief. Traumatology, 14(1), 127-139.

Flint, G. A., Lammers, W., \& Mitnick, D. G. (2006). Emotional Freedom Techniques: A Safe Treatment Intervention For Many Trauma Based Issues. Journal of aggression, maltreatment $\mathcal{E}$ trauma, 12(1-2), 125-150.

Handayani, D. Y., \& Dewi, D. E. (2016). Analisis Kualitas Hidup Penderita dan Keluarga Pasca Serangan Stroke (Dengan Gejala Sisa). Psycho Idea, 7(1), 35-44.

Hariyati, R. T. S., Yetti, K., \& Hakam, M. (2009). Intervensi Spiritual Emotional Freedom Technique Untuk Mengurangi Rasa Nyeri Pasien Kanker. Makara Seri Kesehatan, 13(2), 91-95.

Haynes, T. (2010). Effectiveness of emotional freedom techniques on occupational stress for preschool teachers. Psychology Journal, 6(2), 34-46.

Karangora, M. L. B., Yudiarso, A., \& Mazdafiah, S. Y. (2012). Hubungan Antara dukungan sosial dan kualitas hidup pada lesbian di Surabaya. Calyptra, 1(1), 1-9.

Karatzias, T., Power, K., Brown, K., McGoldrick, T., Begum, M., Young, J.Adams, S. (2011). A controlled comparison of the effectiveness and efficiency of two psychological therapies for posttraumatic stress disorder: eye movement desensitization and reprocessing vs. emotional freedom techniques. The Journal of nervous and mental disease, 199(6), 372-378.

Kimbrough, E., Magyari, T., Langenberg, P., Chesney, M., \& Berman, B. (2010). Mindfulness intervention for child abuse survivors. Journal of clinical psychology, 66(1), 17-33.

Lane, J. (2009). The Neurochemistry of Counterconditioning: Acupressure Desensitization in Psychotherapy. Energy Psychology: Theory, Research, and Treatment, 1(1), 31-44.

Latipun. (2015). Psikologi eksperimen (3rd ed.). Malang: UMM Press. 
Mardiyono, M., Songwathana, P., \& Petpichetchian, W. (2011). Spirituality Intervention And Outcomes: Corner Stone of Holistic Nursing Practice. Nurse Media Journal of Nursing, $1(1), 117-127$.

Nurhasanah. (2008). Hubungan tingkat depresi dengan kualitas hidup pada daerah bencana pasca gempa bumi di Kabupaten Sleman tahun 2008. Universitas Gadjah Mada, Yogyakarta.

NurrieStearns, M., \& NurrieStearns, R. (2013). Yoga for Emotional Trauma: Meditations and Practices for Healing Pain and Suffering. Oakland: New Harbinger Publications.

Pan American Health Organization. (2006). Bencana alam: Perlindungan kesehatan masyarakat. Jakarta: EGC.

Primardi, A., \& Hadjam, M. N. R. (2011). Optimisme, harapan, dukungan sosial keluarga, dan kualitas hidup orang dengan epilepsi. Jurnal Ilmiah Psikologi, 3(2), 123-133.

Putri, D. N. R. S. (2016). Pelatihan Kebersyukuran Untuk Meningkatkan Kualitas Hidup Pada Lansia (Tesis). Universitas Ahmad Dahlan, Yogyakarta.

Ramli, S. (2010). Pedoman Praktis, Manajemen Bencana. Jakarta: Dian Rakyat.

Rubbyana, U. (2012). Hubungan Antara Strategi Koping Dengan Kualitas Hidup Pada Penderita Skizofrenia Remisi Simptom. Jurnal psikologi klinis dan kesehatan mental, 1(02), 59-66.

Sadli, S. (2010). Berbeda Tapi Setara. Jakarta: PT. Kompas Media Nusantara.

Salim, O. C., Sudharma, N. I., Kusumaratna, R. K., \& Hidayat, A. (2016). Validitas dan reliabilitas World Health Organization Quality of Life-BREF untuk mengukur kualitas hidup lanjut usia. Universa Medicina, 26(1), 27-38.

Sarafino, E. P., \& Smith, T. W. (2014). Health Psychology: Biopsychosocial Interactions. London: John Wiley \& Sons.

Sekarwiri, E. (2008). Hubungan antara kualitas hidup dan sense of community pada warga DKI Jakarta yang tinggal di daerah rawan banjir (Tesis). Universitas Indonesia, Jakarta.

Sulistyarini, I. (2013). Terapi Relaksasi Untuk Menurunkan Tekanan Darah Dan Meningkatkan Kualitas Hidup Penderita Hipertensi. Jurnal Psikologi, 40(1), 28-38.

Ulfa, E. (2013). Intervensi Spiritual Emotional Freedom Technique Untuk Menurunkan Gangguan Stres Pasca Trauma Erupsi Gunung Merapi. Journal of Educational, Health and Community Psychology, 2(1), 38-57.

V Wardhani. (2006). Gambaran Kualitas Hidup Dewasa Muda Berstatus Lajang Melalui Adaptasi Instrumen Whoqol-Bref Dan SRPB. Universitas Indonesia, Depok.

Vernon, L. L., Dillon, J. M., \& Steiner, A. R. (2009). Proactive coping, gratitude, and posttraumatic stress disorder in college women. Anxiety, Stress, \& Coping, 22(1), 117-127.

Wardiyah, M. (2013). Group Positive Psychotherapy Untuk Meningkatkan Kesejahteraan Psikologis Remaja. Jurnal Sains dan Praktik Psikologi, 1(2).

Yulaelawati, E. (2008). Mencerdasi Bencana: Banjir, Tanah Longsor, Tsunami, Gempa Bumi, Gunung Api, Kebakaran. Jakarta: Grasindo.

Zainuddin, A. F. (2006). Spiritual Emotional Freedom Technique (SEFT). Jakarta: Afzan Publishing. 